\title{
Some Dilemmas Regarding Teacher Training: On the Teacher's (Not) Being a Role Model
}

\author{
Hasan Şeker ${ }^{1}$, Sabahattin Deniz ${ }^{1}$ \\ ${ }^{1}$ Curriculum and Instruction Faculty of Education, Muğla Sıtkı Koçman University, Mugla, Turkey \\ Correspondence: Hasan Şeker, Curriculum and Instruction Faculty of Education, Muğla Sitkı Koçman University, 48000 \\ Mugla, Turkey
}

Received: September 14, 2015 Accepted: October 9, 2015 Online Published: October 19, 2015

doi:10.11114/jets.v4i2.1086

URL: http://dx.doi.org/10.11114/jets.v4i2.1086

\begin{abstract}
In the research, the primary and secondary school teachers' styles of teaching, beliefs and applications related to the teaching approach have been analyzed in terms of teaching applications. In the research, in which descriptive and qualitative analyses have been carried out, mixed method has been used. The research has been performed with totally 200 teachers consisting of 106 women, 94 men who are in charge in primary and secondary schools. In the research Anthony F. Grasha - Sherly Wetter Reichmann Learning Style scale and the constructivist learning environment scale developed by Tenenbaum, Naidu, Jegede and Austin have been used. Besides the diaries ( 80 diaries) written within the context of teaching applications by the 24 senior students in Faculty of Education have been analysed. Along with that the teachers have high levels of modelling, encouraging individualism, personal, advisor and counsellor teaching styles, it is seen that they have the teaching styles of information conveyor on a level higher than intermediate, and authoritative teaching style to a great extent. In the teacher candidates' pre-service education, the differences between the existence of the role models "inappropriate" for the system or the approach and the beliefs and applications may cause the teacher candidates to suffer from some errors with regard to the role models in the education process.
\end{abstract}

Keywords: constructivist approach, school-based education, teaching style, training teachers, role model

\section{Introduction}

It is witnessed that in the teacher training system in Turkey it is important for the teacher candidates to make an on-the-job training to some extent through the school experiences gained at the practice school and the lessons of teaching applications. According to the on-the-job learning paradigm, the teaching skill is primarily acquired by training "apprenticeship" under the supervision of an experienced teacher (Yıldırım 2011). The teacher candidate gains the teaching skill through practice by observing the teacher on the job and fulfilling the tasks assigned by him/her. He/she puts the skills he/she has learned into practice and receives feedback from the experienced teacher. Within this period, the experienced teacher helps the candidate recognize his/her weaknesses and strengths and develop his/her deficient skills (2011). Within this period, the practising teachers are in a significant position for the teacher candidates.

As in the other countries, in Turkey, the teacher candidates are trained on the job by practising in a "job-based" way. In this respect, it is seen that the school-based experiences take an important place in the process of training teachers. For the school-based training approach, it is desired for the teacher candidates to develop their knowledge and experiences through the role-model behaviours in the training in accordance with the philosophy of the school practising teachers' curriculum, which is in operation within the practising period. The learning approaches preferred by practice teacher, their teaching styles applied and the role-model behaviours are examined in this study.

In recent years it has been desired for the programs in the education system in Turkey to move from the behavioural linear approach to the more flexible constructivist approach. When the old programs and program applications are examined, the critiques on the dominance of the teacher-centred and behavioural approach generate the basis for preparing a new program. The constructivist approach was regarded as the basis as the learning and teaching approach for the development of the 2004 program (Ministry of National Education [MEB], 2004). In line with this perception, in the programs firm steps were taken from objectives towards the regulations in the process of teaching and learning, from the traditional assessments towards authentic process evaluations. So, comprehensive studies were started for the promotion and practice of the new program during those years. Within the assessments related to the program in 
practice, the researchers stated that the practices of the changeovers in the program could only be available at the end of a longer, tough period (Yavuz, 2005), the new program was on trial, and it was needed to have a period of 5-6 years and to research and discuss on the practising results (Kavak, 2005). Within the first years when the program was put into practice, it was seen that the teachers tried to get used to the constructivist approach (Tabak, 2007), but most of them behaved in a traditional way during the class (Unal and Akpinar, 2006). These findings may be considered as the signs signifying that the period of change was not an easy one.

While the constructivist approach has become the formal philosophy of education in Turkey, the fact that the program practices entirely is "a bit far" from the constructivist practices comes into view in the negotiations performed unsystematically. It is also seen that in the programs some detections are made related to the facts that constructivism is traced for, an objectivist approach is adopted, and thus the program may be described as an ordinary constructivist (Ünder, 2010). Such views and critiques may be a sign that it may generate different "constructivist" forms in deed, in reality and in practices. Almost more than 10 years have passed since the program was in practice for the first time. It is wondered in this research to what extent the changes predicted by the program have reflected on the teacher's behaviours in class and the class atmosphere during this period. It is considered that the teachers can display role-model behaviours "appropriate" for the program with the reflections of the changes in the constructivist approach predicted in the program on the teacher's behaviours. Role models mediate for the teacher candidates to find their own ways. It is observed that during the training process the teacher candidates are influenced by the role models and the academicians may become significant role models for the candidates, they consider academicians' personal characteristics, communication skills and teaching styles as models and feature and practice those role models more or less in their lives (Tonga, 2014). Apart from the academicians' role-model behaviours to a great extent, it is also understood that the teachers in secondary education are role models by whom the students are influenced the most (Timmerman, 2009). Within the teacher-training period, the teachers' being role models are deemed considerably important in terms of learning styles of the students who are teacher candidates (Shein and Chiou, 2011). Though the teacher trainers are role models mostly for the subject area knowledge, it is also witnessed that the second-degree teacher trainers' modelling regarding the teaching behaviours has more or less influence on the secondary school teachers (Timmerman, 2009).

Style is the way to do something as a teacher (Joan, 1991). Teaching style refers to teachers' decisions on problem solving and teaching process (Fan and Ye, 2007). Personal characteristics, experiences, belief regarding education, philosophy, values, and context have influence on the styles (Joan, 1991). It is assumed that in practice for the knowledge, approach and beliefs (not) to reveal themselves in application may partially depend on the teaching styles that the teachers have. This situation in theory, belief and practice -if differences may occur- may cause the teacher candidates to confront "inappropriate" role models during pre-service and to have some fallacies in teacher training period.

In students' learning, a shift from the traditional approach to constructivism, from the teacher-centred approach to student-centred approach, from the learner's memorizing the knowledge to higher thinking skills, from the behavioural basis to constructivist basis is received broad acceptance in teacher training (Leu, 2004). Tendencies from the class routines presented as rigid prescriptions towards learning by taking more flexible reflective practices as model; from models in which the works are sorted in a row (cascade model) towards models participated by all the teachers and performed by an expert; from the positivist-based teacher learning towards the constructivist-based teacher learning are crucial to the learning communities in the school-based model in which professional cooperation highly exists. Regularly gathering, these communities aim constantly to increase the learning of both themselves and their students (Lieberman and Miller, 2008). In these communities increases in professional learning among the participants are witnessed in terms of common responsibilities and objectives (Lieberman and Miller, 2011). Different objectives provide lots of benefits in these communities and there is a strong cooperation between the practice teachers with regard to learning-teaching process (McLaughin and Talbert, 2006: 19). In school practices, cooperation between the teacher candidates, school practice teachers and the faculty practice members is desired, though partially, within the learning communities. The teacher-training paradigm bearing the features of 'on-the-job training approach' by Zeichner maintains its effectiveness today in teacher training programs (Yıldırım, 2011). In this research, the opinions of the primary and secondary school teachers on constructivist teaching approaches and the reflections of these opinions on practices are analyzed within the scope of the teachers' teaching styles; moreover, to what extent and how the school practice teachers who play a great role in pre-service training of the teacher candidates display the examples of a "role model" is discussed.

In this regard, answers to the following questions have been sought for in the research:

1. In primary and secondary school teachers' opinions, to what extent is it behaved appropriate for the constructivist approach in the learning environment? 
2. Which teaching style do the teachers have mostly?

\section{Method}

In the research in which the opinions of primary and secondary school teachers on the constructivist teaching approaches and the teaching styles are examined, the mixed method in which the qualitative and quantitative data are analysed has been used.

\subsection{Research Group}

The research has been carried out with totally 200 teachers consisting of 106 women and 94 men. It has been performed on the primary and secondary school teachers in central Muğla, $88(44 \%)$ of whom are class teachers, $112(56 \%)$ of whom are secondary school teacher at different branches. Moreover, in the research the diaries ( 80 diaries) written by 24 senior students studying at the Faculty of Education within the context of teaching practices have been analysed in the research. The seniorities of the teachers in the research group are given on Table 1.

\begin{tabular}{lll}
\hline Seniority & f & \% \\
\hline 0-5 years & 12 & 6 \\
6-15 years & 45 & 22.5 \\
16-25 years & 59 & 29.5 \\
$26+$ & 80 & 41 \\
Total & 196 & 98 \\
Unanswered & 4 & 2 \\
\hline
\end{tabular}

Analysing the seniorities of the teachers, it is witnessed that almost $70 \%$ of them have seniorities of 16 -year or more while the teachers having working experiences of 26 years and more account for the $41 \%$ of the research group.

\subsection{Data collection Tools}

In the research Anthony F. Grasha - Sherly Wetter Reichmann Learning Style Scale, which is composed of 40-question, has been used. The scale consisting of five subcategories has been adapted to Turkish, and the interpersonal language consistencies of the scale whose preferred styles by the trainers during the training are the sub-dimensions of information conveyor, authoritative, personal, counsellor and advisor have been calculated as .80 , and the alpha reliability coefficient as .88 (Sarıtaş and Süral, 2010). The alpha reliability in our scale research sample has been detected as .91 . The scoring and the classification of the scale sub-dimensions are as follows:

\begin{tabular}{lccc}
\hline & Low & Medium & High \\
\hline Information Conveyor & {$[1.0-2.8]$} & {$[2.9-3.8]$} & {$[3.9-5.0]$} \\
Authoritative & {$[1.0-1.8]$} & {$[1.9-3.0]$} & {$[3.1-5.0]$} \\
Personal & {$[1.0-2.8]$} & {$[2.9-3.4]$} & {$[3.5-5.0]$} \\
Counsellor & {$[1.0-2.9]$} & {$[3.0-4.0]$} & {$[4.1-5.0]$} \\
Advisor & {$[1.0-1.8]$} & {$[1.9-2.8]$} & {$[2.9-5.0]$} \\
\hline
\end{tabular}

Source: http://www.iats.com/publications/GLSI.html) the alpha reliability coefficient is calculated as .875 (Sarıtaş and Süral, 2010).

The constructivist learning environment scale developed by Tenenbaum, Naidu, Jegede and Austin (2001) consists of 30 questions. The scale, by which the teachers' skills of arranging constructivist environment are detected, has been adapted by Fer and Cirrk (2006). The Pearson correlation coefficients between the practices in Turkish and English carried out for the language equivalence of the scale vary from 0.46 to 0.80 . In the factor analysis performed to detect the construct validity of the scale, a construct in teacher form with 5 factors and 30 items have appeared, and the alpha reliability of the scale has been calculated as .95 (Fer and Cırık, 2006). The alpha reliability of the scale applied on the research group has been calculated as .91 . The scale consists of seven sub-dimensions.

- Discussions and interviews (Cons1)

- Conceptual contradictions (Cons2)

- $\quad$ Sharing the opinions with others (Cons3)

- Materials and sources' aiming to lead to the solution (Cons4)

- Motivating for the reflection and concept reconnaissance (Cons5)

- $\quad$ Satisfying the learner's needs (Cons6)

- Forming the meaning and link to the real-life experiences (Cons7)

Additionally the diaries ( 80 diaries) written within the context of teaching applications by the 24 senior students at Faculty of Education have been analysed.

\subsection{Data Analyses}

For analysing the data, along with some analyses such as $\mathrm{f}, \%$, mode, median, average, standard deviation, one-way factor analysis has been applied. 


\section{Findings and Comments}

The points and point averages that the primary and secondary school teachers in the research group have scored at the seven sub-dimensions of the constructivist learning environment scale are indicated on Table 2.

Table 2. Point distributions scored by the teachers for the constructivist learning environment scale

\begin{tabular}{lccccccc}
\hline & Cons 1 & Cons 2 & Cons 3 & Cons 4 & Cons 5 & Cons 6 & Cons 7 \\
\hline Mean & 4,15 & 2,22 & 4,32 & 4,33 & 4,15 & 3,88 & 4,19 \\
Median & 4,20 & 2,00 & 4,25 & 4,33 & 4,17 & 3,80 & 4,25 \\
Mode & 4,60 & 1,00 & $4,00(\mathrm{a})$ & 5,00 & 5,00 & 4,00 & 4,00 \\
Standard &, 62 & 1,01 &, 53 &, 54 &, 64 &, 66 &, 56 \\
deviation & 200 & & & & & & \\
n & & & & & & \\
\hline
\end{tabular}

According to the findings in Table 2, it is indicated that in all the dimensions of the constructivist teaching environment scale, the class and branch teachers are in compliance with suitable practices for the constructivist-teaching environment. According to the sub-dimensions of the scale, teachers score almost 4 on average out of 5 . The fact that the average score is approximately 2 in the second dimension (Cons2) is because the questions $\left(6^{\text {th }}-8^{\text {th }}\right)$ in this dimension, which are related to the conceptual contradictions, are the negative questions. For instance, the $6^{\text {th }}$ question which is "The lessons have caused students to have contradictions" has been reacted as barely agree by the teachers.

The teaching environment of the teachers in the research group is generally depicted as constructivists. A similar finding is also observed in the research by Turan and Erden (2010). In the said research it is of the opinion that the class teachers' skills of arranging constructivist class environment are fine.

According to the research findings, meaningful differentiations between the class and branch teachers $\left(1^{\text {st }}\right.$ and $2^{\text {nd }}$ seniority teachers) are not observed in terms of constructivist teaching environment through all the dimensions of the scale (Cons1 F:.271, Cons2 F. 1.714, Cons3 F:.366, Cons4 F: 1.703, Cons5 F:1.426, Cons6 F: 1.353, Cons7 F:.528). With regard to these findings, both the class and branch teachers are of the opinion that they have a good level of skills of arranging constructivist class environment.

The score distributions related to the research group teachers' teaching styles applied in teaching process are shown below in Table 3.

Table 3 . The teaching styles applied by teachers in teaching

\begin{tabular}{|c|c|c|c|c|c|c|c|c|c|}
\hline Teaching style & $\begin{array}{l}\text { Low } \\
\text { Score } \\
\text { interval }\end{array}$ & f & $\%$ & $\begin{array}{l}\text { Medium } \\
\text { Score } \\
\text { interval }\end{array}$ & $\mathrm{f}$ & $\%$ & $\begin{array}{l}\text { High } \\
\text { Score } \\
\text { interval }\end{array}$ & f & $\%$ \\
\hline Information Conveyor & $1-2.28$ & 14 & 7 & $2.9-3.8$ & 174 & 87 & $3.9-5.0$ & 12 & 6 \\
\hline Authoritative & $1-1.8$ & 0 & 0 & $1.9-3.0$ & 17 & 8.5 & $3.1-5.0$ & 183 & 91.5 \\
\hline Personal & $1-2.8$ & 1 & 5 & $2.9-3.4$ & 13 & 6.5 & $3.5-5.0$ & 186 & 93 \\
\hline Counsellor & $1-2.9$ & 2 & 1 & $3.0-4.0$ & 62 & 31 & $4.1-5$ & 136 & 68 \\
\hline Advisor & $1-1.8$ & 0 & 0 & $1.9-2.8$ & 3 & 1.5 & $2.9-5.0$ & 197 & 98.5 \\
\hline
\end{tabular}

The findings shown in Table 3 indicate that the teachers are information conveyors at a level above medium, authoritative at a rate of $91.5 \%, 93 \%$ personal such as modelling, encouraging individualism, advisor at a rate of $98.5 \%$, and have a high-level of counselling teaching style of $68 \%$. In the light of these findings, it can be said that the teachers in the research group either have both behavioural (information conveyor, authoritative) and constructivist (considering individual education having advising, counselling teaching styles) approaches or they perform the teaching styles which are considering individual education, advising and counselling through the role of information conveyor and authoritative. According to these findings, it is seen that the teachers apply different teaching styles at class. In Table 4, the score distributions of the teachers gain from the sub-dimensions of teaching styles are shown.

Table 4. The teaching styles of teachers

\begin{tabular}{llllll}
\hline & $\begin{array}{l}\text { Information } \\
\text { Conveyor }\end{array}$ & Authoritative & Personal & Counsellor & Advisor \\
\hline Arithmetic & 3,43 & 3,84 & 4,07 & 4,28 & 3,98 \\
Average & 3,50 & 3,86 & 4,00 & 4,31 & 4,00 \\
Median & 3,63 & 4,00 & $3,88(\mathrm{a})$ & 4,63 & 4,00 \\
$\begin{array}{l}\text { Mode } \\
\text { Standard }\end{array}$ &, 35 &, 53 &, 48 &, 45 &, 47 \\
deviation & 200 & & & & \\
n & & & & &
\end{tabular}

The findings in Table 4, similarly to the ones in Table 3, display that the teachers have both the personal, counselling 
and advising teaching styles and authoritative, information conveying styles. Analysing thoroughly the teaching styles of the teachers in the research group, we can observe that they have a medium level of information conveying, and high levels of authoritative, personal, counselling and advising teaching styles. These findings vary statistically in the analyses carried out, depending on the grades at which the teachers fulfil their duties (first grade - primary school and second grade - secondary school) (Information conveying F: .353, Authoritative F: .658, Personal F: 1.006, Counsellor F: .296, Advisor F: .784). Although the findings indicate that the teachers at both grades mostly use the constructivist-teaching environment, in practices it is seen that they also have a perception of information conveying and authoritative.

The school practice assessments of the students at the Faculty of Education have been analyzed. For these evaluations, the diaries written by the teacher candidates with respect to such titles as the teaching methods, the lesson management and the control over class have been examined.

\section{In the diaries of teacher candidates}

The teaching methods and approaches of the teachers:

Within the diaries of the teacher candidates, the methods used by practice teachers have been analysed. It is seen that the teacher candidates summarize the behaviours of practice teachers who apply "student-based" approaches. With regard to this subject the reactions of two teacher candidates are below:

...our teacher teaches the lessons appropriately for the constructivist teaching approach; provides opportunities for the students to be curious, express themselves, and is attentive to make them have a critical point of view (Teacher Candidate a)

...our teacher made the students reach the information on their own, did not relay information directly. I realized that the teacher used the constructivist approach... (Teacher Candidate b)

The above stated examples show that the teachers display the features of the constructivist approach. However, that the most of the practice teachers teach their lessons in accordance with the behavioural perspective are reflected on the diaries of the teacher candidates.

For example:

...Our teacher made a student randomly chosen read the text about the subject to be discussed from the course book. Then, teacher continued the lesson by interpreting the text read and explaining the important points in the text to the students. .. While explaining the subject, the teacher frequently asked questions to students with the aim of short reviews. ...The students tried to take notes of the parts containing the important information by marking or underlining... (Teacher Candidate c).

...our teacher adopted the lecture method in class... our teacher is of a classic teacher type... The teacher employed lecture method, and conveyed information directly to the student... (Teacher Candidate d)

... In view of covering the subject and writing the important points on the board, mostly a teacher - based instruction was conducted ... (Teacher Candidate e).

...during the lessons I have participated so far, the teacher generally conveyed information to students by the method of presentation due to the content of the subjects... The teacher enriched the lecture by using instruments... (Teacher Candidate $\mathrm{f}$ )

...the teacher, whom we observe, generally uses the traditional lecture method. Through the lecture method, the teacher conveys more beneficial and reliable information to students... (Teacher Candidate g).

... The teacher preferred plain and traditional lecture method; supported this lecture with question and answer teaching method. It was observed that the teacher always sat at teacher's desk and never left there... (Teacher Candidate s)

...our practice teacher usually applies the traditional lecture method and a teacher-based practice in accordance with the schedule book... The primary reason behind adopting this method is that the classroom is very crowded... Our teacher prefers to use lecture method at a rate of $60 \%$... (Teacher Candidate sp).

... the teacher taught the lesson by using the lecture method, asked some questions to make them think and inspect their knowledge through the question and answer method. ... The teacher only made use of the images in the book in terms of visuality... (Teacher Candidate 1).

The abovementioned reactions indicate that the practice teachers display more-or-less behavioural, teacher-based approach in their classes. As also understood from the reactions above, the classroom size and course subject affect the approach preferences. 


\section{Control over class}

According to the teacher candidates' diaries, few candidates consider the teachers, who they observe, more flexible and constructive in terms of class management. Here below is the opinion of a teacher candidate regarding this subject.

...whether a lesson was effective or enjoyable or none may be understood from the behaviours of the students at the end of that lesson. ...I can say that I have witnessed the lesson has been effective and enjoyable as the teacher has chosen an appropriate method and supported that with suitable materials, and presented an appropriate environment... (Teacher Candidate q).

... Our teacher praises the students wittily when they give correct answers, explains without offending for the ones making mistakes that their answers are not wrong completely, and help the student to find out the correct one.... (Teacher Candidate h).

The diaries of the teacher candidates indicate that they have witnessed that the practice teachers prefer mostly a strict discipline manner in the class environment. Regarding this subject, the teacher candidates express the opinions below:

... If students misbehave in class, disturb the lesson... they should not be scolded and offended immediately. What I'm trying to say... our teacher has deficiencies in that matter, even if just a bit, however, accordingly students are generally pleased with our teacher... (Teacher Candidate $\mathrm{j}$ ).

... Based on the observations I have made, I have witnessed that the greatest deficiency of teachers is their limited communication with students, their keeping themselves at a distance, not making the students feel that each is an individual... (Teacher Candidate $\mathrm{k}$ ).

...the teacher started to lecture on the subject by making a brief introduction. The teacher started to make an eye contact with the students, thus influenced the students positively and increased the students' listening to the lecture... the teacher secured the authority in class by raising tone of voice sometimes... (Teacher Candidate kk).

... as it was the first day of the week, the students could not get adapted to the lessons. On the one hand they were listening to the teacher, and on the other hand they were talking among themselves. ... the warnings by our teacher worked out but did not go a long way. (Teacher Candidate 1).

... when the bell rings, the students sit down to their seats, they show respect and stand up when the teacher enters the class and the teacher asks them to open their books... The teacher begins the subject by questioning the knowledge of the students and by correcting the wrong information. (Teacher Candidate $\mathrm{z}$ ).

$\ldots$ in case of the inability to ensure the tranquillity despite the efforts, the teacher reminds that these subjects will be included on the exams. ...The teacher raises voice sometimes against the students continuing making noise... (Teacher Candidate $\mathrm{u}$ ).

...the teacher does not want a student to speak in class without giving the student the right to speak, likewise the teacher achieves dominance by making the others listen to him/her, while a student is speaking. ... (Teacher Candidate o).

... When our teacher came to the class, all the students were on their feet and messy. The teacher tried to bring order into the class by first looking the students in the eyes and then telling them loudly to sit down... (Teacher Candidate $p$ ).

...when I attended the second class, most of the students were adapted to the lesson and seated in a position ready to listen to the teacher... (Teacher Candidate $\mathrm{m}$ ).

...there were a lot of students in the class, who concerned themselves with some other stuff and constantly disturbed their friends. The teacher waited for the students' behaviours to die away first by ignoring them during the class. However, this method did not work out well. As a second method, the teacher tried to make them attend the lesson by asking them questions. Finally, when this method failed as well, the teacher intervened by warning them harshly and loudly... (Teacher Candidate $\mathrm{n}$ ).

The above stated examples indicate that the teachers mostly behave in a disciplining way. It is clear that this finding corresponds with the finding that, as for the teaching styles, the teachers mostly have the authoritative one.

According to the teacher candidates in the research group, the way the practice teachers share the information with their students is summarized within the reactions below.

\section{Information transfer-sharing methods of the practice teachers:}

According to the diaries of the teacher candidates, it is seen that the practice teacher convey the subjects in a way strictly-dependent on the course materials. In this regard, the teacher candidates have expressed the opinions below:

... the students listen to the subject mostly from the teacher, they only make use of the book to do homework and follow the subject. (Teacher Candidate an). 
...After making an introduction to lesson related to the subject, the teacher asks the students to open the related pages in their books and ask one of them to read the subject loud from the book. Other students follow their friend reading the subject... (Teacher Candidate gn).

... the teacher conducted activities by following the order in the book. (Teacher Candidate tr).

... as a first step, our teacher makes the student read the book during the lesson, proceeds the reading activity by following either a certain order from the list or the order of seating in order not to cause confusion and disorder. (Teacher Candidate hh).

... the teacher first makes the students read the subjects and asks the ones, who want to speak on the subject, to raise their hands and get the right to speak. (Teacher Candidate gh).

... after informing the students about the subject, the teacher makes them read it and underline the details deeming significant after asking warm-up questions. (Teacher Candidate oop).

The teacher candidates are of the opinion that the practice teachers have a strict approach in information conveying throughout the lesson. The finding that the information is generally conveyed by the teacher according to a certain row and order conflicts with the finding that the practice teachers have a lesser level of information conveying teaching style. There are observed some contradictions between the opinions of teacher candidates and teachers in terms of conveying and sharing information.

\section{Discussion and Conclusion}

According to the research findings, the 200 primary and secondary school teachers in the research group are of the opinion that they operate in practices appropriate for the constructivist teaching environment in all the dimensions of the constructivist teaching environment scale such as sharing the opinions with others, meeting the needs of the learner, forming meanings and linking them to real-life events. With regard to the research findings, they have stated that both the form and branch teachers are in practices appropriate for the constructivist-teaching environment in all the dimensions of the constructivist teaching environment scale. To what extent these positive opinions of the teachers on the constructivist-teaching environment reveal themselves has been analysed in the research. This analysis has been carried out by means of the teaching styles scale, which is another test, applied on the teachers and the reports, which the teacher candidates have kept about the behaviours of the practice teachers during the class. Analysing the teaching styles of the teachers within this framework, it is seen that they have high levels of modelling, advising, counselling teaching styles. However, examining the teaching styles the teachers have, it is observed that they have the teaching styles of information conveyor on a level higher than intermediate and authoritative teaching style to a great extent. These findings indicate that, beyond the opinions and beliefs of the teachers sampling towards the constructivist approach in their practices, they display practices different from this belief, and that they are constructivist in theory but behave in a more behavioural approach in practice. Although the teachers at the both grades state that they are on the side of the constructivist teaching environment, it is observed in the research that they also have considerably information conveying and authoritative perception in practice. In other words, it can be said that the teachers' positive opinions or beliefs on the constructivist teaching environment do not reflect similarly on the teaching environment, and there is also a strict behavioural approach taking place in practices, as well as the constructivist examples. While the constructivist approach has become the formal philosophy of education in Turkey, the fact that the program practices entirely is "a bit far" from the constructivist practices comes into view in the negotiations performed unsystematically. Considering the facts that in the programs some detections are made related to the facts that constructivism is traced for, an objectivist approach is adopted, and thus the program may be qualified as the ordinary constructivist (Ünder, 2010); it may also be inferred that this situation may cause the teacher candidates to have some dilemmas within the school experiences and school practices process.

The research findings show that the teachers have information conveying, authoritative, advising and a high level of counselling styles in terms of teaching styles. It may be possible to discuss this finding in two ways. First, it may be considered that the teachers in the research group either have both behavioural (information conveyor, authoritative) and constructivist (considering individual education, having advising, counselling teaching styles) approaches, and/or secondly, they perform the teaching styles which are considering individual education, advising and counselling with an approach of information conveyor and authoritative. Though they are not hard evidences, this situation indicate that the teachers apply their teaching styles in the classes in a different or sometimes conflicting way. In the teacher candidates' overall evaluations reflected on the diaries regarding the school practice process, in a supportive way for the above evaluations, it is seen that the teachers display the examples of constructivist approach, most of the practice teachers teach the lessons in an appropriate way for the behavioural perspective, they display approaches which are more or less behavioural and teacher-centred in class, and they behave mostly in a disciplining manner. Considering that the beliefs related to teaching are not reflected enough on practice and our old traditions of teaching and learning process constitute 
resistance to change (Şeker, 2010, 2011), it is possible to noticeably eliminate the inconsistencies between the theory, beliefs, habits and practices through the existence of the practicing samples which are "appropriate", sufficient in number and quality and the role-model behaviours. Thus, it is possible to progress in having a boarder, clearer point of view over the teaching system by means of "more consistent" role model samples in the school practices of teacher candidates. Considering the fact that the expected approach in both teacher training and school programs is the cognitive-based - constructivist approach is not enough for it to be emphasized within the programs; likewise, that the teachers in the research group have beliefs mostly in the constructivist philosophy do not constitute sufficient condition for them to behave in an appropriate way for the philosophy of the approach. The discrepancy between the beliefs and practices may cause the teacher candidates to have fallacies about the learning-teaching process. For example, a teacher candidate's statement "my greatest inference from the two classes I attended throughout the semester is that the students are well-informed and capable of asking unexpected questions at any moment... As well as the constructivist system, it is also required to use traditional methods in order to keep the students under control" is expressed through the remark that the traditional system is used as a means of disciplining or the constructivist approach has no or too little influence on maintaining the control over class. Another teacher candidate has stated that most of the teachers convey information during the class and this may be used as a means of disciplining in case of crowded classes. While it is hard to generalize through the students' reactions above, the research findings may show that there may be some concerns regarding the sufficiency of the theoretical information on learning and teaching approaches during the pre-service training process of teachers. To learn and teach qualitatively the learning and teaching approaches during the teacher training process can serve the purpose for the teacher candidates to work up the connection between theory and practice.

\section{Referances}

Fan, W., \& Ye, S. (2007). Teaching styles among Shanghai teachers in primary and secondary schools. Educational psychology: An International Journal of Experimental Educational Psychology, 27(2), 255-272. http://dx.doi.org/10.1080/01443410601066750

Fer, S., \& Cırık, İ. (2006). Öğretmenlerde ve öğrencilerde, yapılandırmacı öğrenme ortamı ölçeğinin geçerlik ve güvenirlik çalışması nedir? Yeditepe Üniversitesi Eğitim Fakültesi Dergisi, 2(1), 2-26.

Joan, D. (1991). Organising learning in the primary school classroom. Great Britain: Routledge Falmer Publishing.

Kavak, Y. (2005). Eğitimde yansımalar: VIII Yeni ilköğretim programını değerlendirme sempozyumu ardından. Çağdaş Ĕgitim, 325, 10-11.

Leu, E. (2004). The Patterns and Purposes of School-based and Cluster Teacher Professional Development Programs. Working Paper \#2 under EQUIP1's Study of School-based Teacher Inservice Programs and Clustering of Schools, U.S. Agency for International Development Cooperative Agreement No. GDG-A-00-03-00006-00

Lieberman, A., \& Miller, L. (2008). Teachers in professional communities: Improving teaching and learning. New York: Teachers College Press.

Lieberman, A., \& Miller, L. (2011). Learning communities. The starting point for professional learningis in schools and classrooms. http://learningforward.org/docs/august-2011/lieberman324.pdf?sfvrsn=2

McLaughin, M. W., \& Talbert, J. E. (2006). Building school- based teachers learning communities. Professional strategies to improve student achievement. Teachers Collage Pres.

MEB (2004). Talim Ve Terbiye Kurulu Başkanlığı Fen ve Teknoloji Dersi Programı İlköğretim 4-5. Sınıf Fen Dersleri Özel İhtisas Komisyonu.

Sarıtaş, E., \& Süral, S. (2010). Grasha - Reichmann öğrenme ve öğretme stili ölçeklerinin Türkçe uyarlama çalışması. E- Journal of New World Sciences Academy, 5(4). 2162-2177.

Şeker, H. (2010). Applicability of the approaches-related beliefs of prospective teachers. Problems of Education in the 21st Century, 25, 138-150.

Şeker, H. (2011). Reflection of teaching approach-related knowledge, beliefs and habits on teaching practice. Problems of Education in the 21st Century, 33, 73-82.

Shein, P. P., \& Chiou, K. T. (2011). Teachers as role models for students' learning styles. Social Behaviour and Personality, 39(8), 1097-1104. http://dx.doi.org/10.2224/sbp.2011.39.8.1097

Tabak, R. (2007). Illköğretim 5. sinıf Fen ve Teknoloji ders programının öğrenme-ögrretme ölçme değerlendirme yaklaşımları kapsamında incelenmesi. Muğla Üniversitesi sosyal Bilimler Enstitüsü, Yayınlanmamış Yüksek lisans Tezi, Muğla.

Tenenbaum, G., Naidu, S., Jegede, O., \& Austin, J. (2001). Constructivist pedagogy in conventional oncampus and distance learning practice: An exploratory investigation. Learning and Instruction, 11, 87-111. http://dx.doi.org/10.1016/S0959-4752(00)00017-7 
Timmerman, G. (2009). Teacher educators modelling their teachers? European Journal of Teacher Education, 32(3), 225-238. http://dx.doi.org/10.1080/02619760902756020

Tonga, D. (2014). A qualitative study on the prospective social studies teachers' role-model preferences. International Journal of Academic Research, 6(1), 94-101. http://dx.doi.org/10.7813/2075-4124.2014/6-1/B.14

Turan, H., \& Erden, M. (2010). Sınıf öğretmenlerinin yapılandırmacı ortam düzenleme becerilerilerinin incelenmesi. EJournal of New World Sciences Academy, 5(4), 1572-1582.

Unal, G., \& Akpınar, E. (2006). To what extent science teachers are constructivist in their classrooms? Journal of Baltic Science Education, 2(10), 40-50.

Under, H. (2010). Manifestations of epistemological theses of constructivism in the science and technology programs of Turkish elementary education. Education and Science, 35(158), 199- 214.

Yavuz, A. (2005). Eğitim dünyamıza çağdaş eğitimin 1şıklı bir yansıması daha düştü. Yeni ilköğretim programını değerlendirme sempozyumu. Çağdaş Ĕ̆itim, 325, 12-18.

Yıldırım, A. (2011). Öğretmen eğitiminde çatışma alanları ve yeniden yapılanma, (Competing agendas and reform in teacher education. Uluslararası Ĕ̈itim Programları ve Öğretim Çalışmaları Dergisi, 1, 1-17.

This work is licensed under a Creative Commons Attribution 3.0 License. 